\title{
Papers
}

\section{Human T cell leukaemia/lymphoma virus infection in pregnant women in the United Kingdom: population study}

\author{
A E Ades, Simon Parker, Jane Walker, Mark Edginton, Graham P Taylor, Jonathan N Weber
}

\begin{abstract}
Objective To assess the prevalence of human T cell leukaemia/lymphoma virus (HTLV) infection in pregnant women in the United Kingdom.

Design Population study.

Subjects Guthrie card samples from babies born in 1997-8. Samples were linked to data on mother's age and ethnic status and parents' country of birth and then anonymised.

Setting North Thames Regional Health Authority. Main outcome measures Presence of antibodies against HTLV in eluates tested by gelatin particle agglutination assay and results confirmed by immunoblot.
\end{abstract}

Results Of 126010 samples tested, 67 had confirmed antibodies to HTLV (59 HTLV-I, 2 HTLV-II, 6 untyped) and six had indeterminate results. Seroprevalence was 17.0 per $1000(95 \%$ confidence interval 9.2 to 28.3 ) in infants whose mothers were born in the Caribbean, 3.2/1000 (1.5 to 5.9) with mothers born in west and central Africa, and 6.8/1000 (3.1 to 12.9) in infants of black Caribbean mothers born in non-endemic regions. In infants with no known risk (both parents born in non-endemic regions and mother not black Caribbean) seroprevalence was 0.06-0.12 per 1000. Mother's country of birth, father's country of birth, and mother's ethnic status were all independently associated with neonatal seroprevalence. An estimated 223 (95\% confidence interval 110 to 350$)$ of the 720000 pregnant women each year in the United Kingdom are infected with HTLV.

Conclusions The prevalence of HTLV and HIV infections in pregnant women in the United Kingdom are comparable. The cost effectiveness of antenatal HTLV screening should be evaluated, and screening of blood donations should be considered.

\section{Introduction}

Human T cell leukaemia/lymphoma virus type I (HTLV-I) is endemic in the Caribbean, Japan, South America, west and central Africa, and isolated pockets elsewhere. It is causally associated with adult $\mathrm{T}$ cell leukaemia/lymphoma and HTLV-I associated myelopathy and tropical spastic paraparesis. ${ }^{1}$ The association of HTLV-II with neurological and lymphoproliferative disorders is less certain. ${ }^{2}$ HTLV-II is endemic in some Amerindian groups and in parts of Africa. ${ }^{1}$ The epidemiology of HTLV in Europe and worldwide has been reviewed recently. ${ }^{3}$ Phylogenetic trees based on nucleotide sequencing have thrown further light on the worldwide distribution of HTLV and its origin in simian $\mathrm{T}$ cell lymphoma/leukaemia viruses. $^{256}$

Both types of HTLV can be transmitted through breast feeding, sexual contact, and blood transfusion and percutaneously. ${ }^{17}$ A high prevalence of HTLV, particularly HTLV-II, has been recorded among injecting drug users in the United States ${ }^{8}$ and parts of Europe. ${ }^{3}$ Blood donors are routinely screened for HTLV in Japan, the United States, Canada, France, the French West Indies, Portugal, Sweden, the Netherlands, Denmark, and Finland.

Rates of transmission from mother to child are $2.7 \%$ in formula fed infants, $5 \%$ with three months' breast feeding, and up to $20 \%$ with prolonged breast feeding. ${ }^{9-11}$ Vertically acquired HTLV-I leads to adult T cell leukaemia/lymphoma in $1-5 \%$ of infected infants. Antenatal screening for HTLV, to recommend formula feeding, has been carried out in the Nagasaki prefecture of Japan since $1987^{12}$ and has been proposed in Europe ${ }^{13-17}$ and Jamaica. ${ }^{18}$

In the United Kingdom, studies of HTLV seroprevalence in pregnant women have been small, local, and confined to multiethnic inner city areas. $^{13} 1416$ 19-21 This study, based on the presence of HTLV specific antibody in neonates, which is a reliable marker of maternal infection, examines the wider seroepidemiology of HTLV in the North Thames region of south east England. This includes inner London, suburban, and remote rural districts. From this we derive estimates of antenatal seroprevalence in the United Kingdom as a whole and discuss the implications for both antenatal and blood donor screening.

\section{Methods}

Population and sources of demographic data The study included all the 126010 non-repeat Guthrie card samples arriving over 15 months in 1997-8 in the North Thames neonatal screening laboratory, which serves almost $15 \%$ of newborn babies in the United Kingdom. Over the last 12 months of the study, demographic data were linked to samples before irreversible unlinking and testing, as described elsewhere. ${ }^{22}$

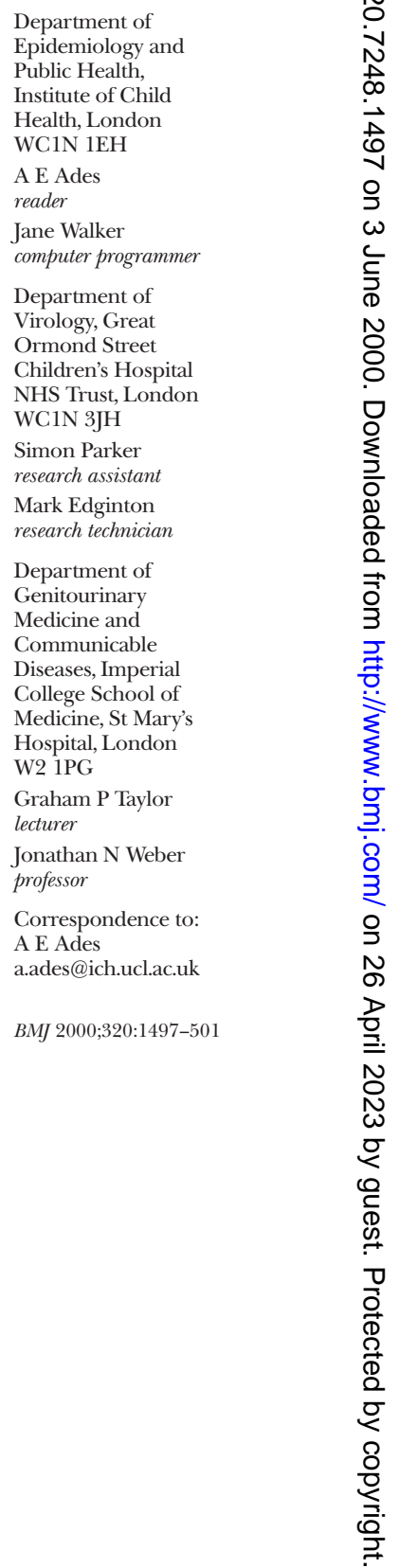


Parents' country of birth, recorded at civil registration of births, was obtained from the Office for National Statistics. Maternal ethnic status and age at delivery was available from child health computers in 14 of the 29 districts in the study. Ethical approval was obtained from local committees covering the study population.

\section{Serology}

Two $4.9 \mathrm{~mm}$ dried blood spot samples were punched into flat bottomed microtitre plates and eluted overnight at $4^{\circ} \mathrm{C}$ in $170 \mu \mathrm{l}$ of eluate buffer. ${ }^{23}$ Eluates were screened by a modified anti-HTLV gelatin particle agglutination assay, which has been shown to be sensitive to anti-HTLV in simulated dried blood spot samples from patients with HTLV-1 from the United Kingdom, South Africa, and Japan. ${ }^{24}$ Tests on serial dilutions of a panel of 23 samples from the HTLV European Research Network showed reliable detection of anti-HTLV-I and anti-HTLV-II in dried blood spot eluates derived from serum samples with titres as low as 1:50. Repeat reactive samples were confirmed and typed by immunoblotting (HLTV blot 2.4,

Table 1 Risk factor distribution of infants with confirmed anti-HTLV positive, indeterminate, and negative eluates. Percentages are given for samples for which presence or absence of risk factors could be determined

\begin{tabular}{|c|c|c|c|c|c|c|c|}
\hline \multirow[b]{2}{*}{ Risk factor } & \multicolumn{4}{|c|}{ Confirmed HTLV } & \multirow[b]{2}{*}{$\begin{array}{c}\text { Indeterminate } \\
(\%)\end{array}$} & \multirow[b]{2}{*}{$\begin{array}{l}\text { HTLV negative } \\
(\%)\end{array}$} & \multirow[b]{2}{*}{ Total } \\
\hline & 1 & II & $\begin{array}{c}\text { Not } \\
\text { Typed }\end{array}$ & Total (\%) & & & \\
\hline Caribbean* & 25 & 0 & 2 & $27(69)$ & $1(25)$ & $2898(7)$ & 2926 \\
\hline $\begin{array}{l}\text { Other endemic } \\
\text { areat }\end{array}$ & 6 & 1 & 3 & $10(26)$ & 1 (25) & 4660 (11) & 4671 \\
\hline No riskł & 1 & 0 & 1 & $2(5)$ & $2(50)$ & 33929 (82) & 33933 \\
\hline Low risk§ & 11 & 0 & 0 & 11 & 1 & 54951 & 54963 \\
\hline No data linkage & 16 & 1 & 0 & 17 & 1 & 29499 & 29517 \\
\hline Total & 59 & 2 & 6 & 67 & 6 & 125937 & 126010 \\
\hline
\end{tabular}

${ }^{*}$ At least one parent born in Caribbean or mother of black Caribbean ethnicity.

tAt least one parent born in west or central Africa, Japan, or South America.

$\Varangle$ ‡oth parents born in non-endemic regions, mother not black Caribbean.

$\S M o t h e r$ born in non-endemic area, but ethnic status or father's country of birth not known.

Table 2 Maternal prevalence of HTLV infection per 1000 including samples with indeterminate results, by mother's country of birth

\begin{tabular}{|c|c|c|c|c|c|c|}
\hline \multirow[b]{2}{*}{ Country of birth } & \multicolumn{3}{|c|}{ Confirmed HTLV } & \multirow{2}{*}{$\begin{array}{c}\text { Total HTLV } \\
\text { (indeterminate) }\end{array}$} & \multirow{2}{*}{$\begin{array}{l}\text { Total } \\
\text { tested }\end{array}$} & \multirow[b]{2}{*}{ Prevalence } \\
\hline & I & II & Untyped & & & \\
\hline \multicolumn{7}{|l|}{ Africa: } \\
\hline Western* & 4 & 1 & 2 & $7(1)$ & 2325 & $3.0-3.4$ \\
\hline Central $^{\star}$ & 1 & 0 & 1 & 2 & 559 & 3.6 \\
\hline Rest of Africa & 0 & 0 & 0 & 0 & 4250 & 0 \\
\hline \multicolumn{7}{|l|}{ America: } \\
\hline Caribbean* & 13 & 0 & 2 & $15(1)$ & 914 & 16.4-17.5 \\
\hline South* & 1 & 0 & 0 & 1 & 490 & 2.0 \\
\hline Central and North & 0 & 0 & 0 & 0 & 801 & 0 \\
\hline \multicolumn{7}{|l|}{ Asia } \\
\hline Japan* & 1 & 0 & 0 & 1 & 233 & 4.3 \\
\hline Rest of Asia & 0 & 0 & 0 & 0 & 12590 & 0 \\
\hline \multicolumn{7}{|l|}{ Europe: } \\
\hline United Kingdom & 22 & 0 & 1 & $23(3)$ & 69013 & $0.33-0.38$ \\
\hline Other northern & 0 & 0 & 0 & 0 & 1948 & 0 \\
\hline Southern & 0 & 0 & 0 & 0 & 1143 & 0 \\
\hline Eastern & 0 & 0 & 0 & 0 & 494 & 0 \\
\hline Western & 1 & 0 & 0 & 1 & 1204 & 0.8 \\
\hline Oceania & 0 & 0 & 0 & 0 & 529 & 0 \\
\hline Missing & 1 & 0 & 0 & 1 & 272 & 0.4 \\
\hline No data linkage & 15 & 1 & 0 & $16(1)$ & 29245 & 0.58 \\
\hline Total & 59 & 2 & 6 & $67(6)$ & 126010 & $0.53-0.58$ \\
\hline
\end{tabular}

*Endemic regions

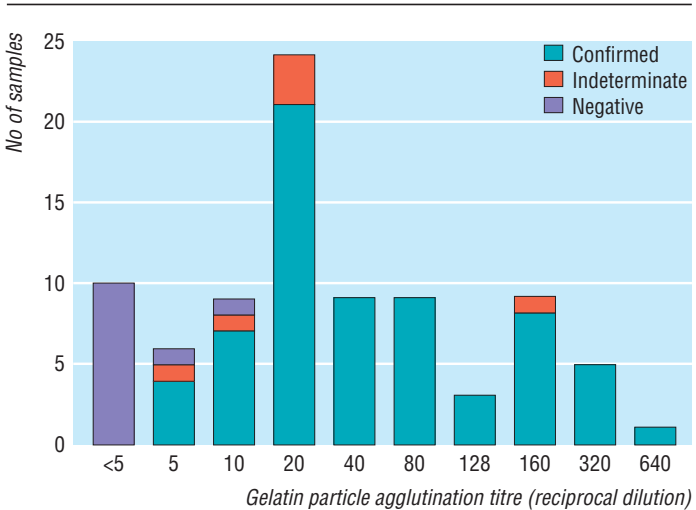

Gelatin particle agglutination titres of reactive eluates

Genelabs Diagnostics, Singapore) at a dilution of 1:50 and according to manufacturer's instructions.

\section{Statistical methods}

We used SAS PROC GENMOD for binomial data to perform multivariate analyses with profile likelihood confidence intervals. Additive risk regression was used to assess the effect of parents' region of birth and mother's ethnic status, ${ }^{25}$ and logistic regression was used elsewhere. Single proportions were compared by Fisher's exact test. We estimated the prevalence of maternal HTLV infection in the United Kingdom by multiplying group specific risks derived from this study and published data into group population sizes estimated from routine birth registration and 1991 census statistics.

\section{Results}

Serology and status of indeterminate samples

Of the 126010 samples tested, 85 were reactive on first gelatin particle agglutination assay and 75 on repeat testing. All 10 samples that were non-reactive on repeat testing gave negative results on immunoblotting. Sixty seven of the 75 repeat reactive samples were confirmed as seropositive (59 HTLV-I, 2 HTLV-II, and 6 HTLV untyped), six were indeterminate, and two were negative. The figure shows the HTLV titres of all 85 initially reactive samples. Six (7\%) samples had titres of 1 in 5, the lowest category above the detection limit, suggesting a false negative rate of no more than $2-3 \%$.

Table 1 compares the demographic features of the babies with indeterminate samples with those of babies with confirmed seropositive and seronegative results. Among those with known risk status, only 18\% (7558/41 487) of babies with negative results had risk factors for infection compared with $37 / 39(95 \%)$ of those with confirmed positive results $(\mathrm{P}<0.0001)$. Two out of four babies with indeterminate samples had a known risk factor. This proportion was not significantly different from that of babies with negative samples $(\mathrm{P}=0.15)$ but significantly lower than in those with confirmed positive samples $(\mathrm{P}=0.037)$. In view of the uncertain status of the six indeterminate samples, we assumed for seroprevalence estimates that half the six indeterminate results were HTLV positive. Confidence intervals incorporate this uncertainty. 
Seroprevalence in relation to demographic factors Maternal prevalence of HTLV infection was highest in Caribbean born women, 16.9 (95\% confidence interval 9.2 to 28.3$)$ per 1000 . Prevalence in women born in western or central Africa was 3.2 (1.5 to 5.9) per 1000. Prevalence was also high in mothers born in Japan and in South America (table 2). These endemic areas accounted for $51 \%$ of maternal infection. The remaining $49 \%$ of infected mothers were born in Europe, where seroprevalence was $0.36(0.21$ to 0.55$)$ per 1000 . The distribution of infection across father's country of birth was very similar.

Maternal ethnic status was known in 40868 cases. In the 29 confirmed and indeterminate cases where ethnic status was known, 15 (52\%) mothers were black Caribbean, five (17\%) black African, and six (21\%) white. There were no cases of HTLV in babies born to the 7495 mothers recorded as Asian or to 571 British born black African women, but there were four confirmed positives cases and two indeterminate among 26905 babies born to white women.

Among 32985 infants with no known risk factors (both parents born in non-endemic areas, mother not black Caribbean) there were two positive and two indeterminate samples (prevalence 0.06-0.12 per 1000). Among infants with a non-black mother born in a non-endemic area, whose only risk was therefore father's country of birth, seroprevalence was $0 / 352$ if the father was born in an endemic area but 2/2347 when the father's country of birth was unknown.

In an analysis of parental country of birth and mother's ethnic status as risk factors for neonatal seropositivity, an additive risk model fitted better $\left(\chi^{2}=32.6\right.$, $\mathrm{df}=38, \mathrm{P}=0.7)$ than a logistic regression model $\left(\chi^{2}\right.$ $=56.3, \mathrm{df}=38, \mathrm{P}=0.028$ ) and gave no significant interactions. Table 3 gives the additional risk of being seropositive conferred by each risk factor, relative to a baseline group of infants with seroprevalence 0.098 per 1000 with no parental risk indicators.
Table 3 Additive binomial regression estimates of the contribution of parents' region of birth and mother's ethnic status on neonatal seroprevalence for HTLV. Central estimates are the average, and confidence limits the most extreme, of those obtained including or excluding indeterminate results as seropositive

\begin{tabular}{|c|c|c|c|}
\hline & $\begin{array}{l}\text { Prevalence per } 1000 \text { births } \\
(95 \% \mathrm{CI})\end{array}$ & $\chi^{2}(\mathrm{df})$ & $P$ value \\
\hline Baseline population* & $0.098(0.017$ to 0.20$)$ & & \\
\hline \multicolumn{4}{|l|}{ Mother's region of birth: } \\
\hline Caribbean & 12.1 (7.5 to 17.7$)$ & \multirow[t]{3}{*}{$42.6(2)$} & \multirow[t]{3}{*}{$<0.0001$} \\
\hline Other endemic & $2.3(0.9$ to 3.0$)$ & & \\
\hline Non-endemic (reference) & 0 & & \\
\hline \multicolumn{4}{|l|}{ Father's region of birth: } \\
\hline Caribbean & 5.4 (2.8 to 8.7$)$ & \multirow[t]{3}{*}{$14.9(3)$} & \multirow[t]{3}{*}{0.0019} \\
\hline Other endemic & $0.1(-0.3$ to 0.3$)$ & & \\
\hline Not registered & $0.3(-0.2$ to 0.8$)$ & & \\
\hline Non-endemic (reference) & 0 & & \\
\hline \multicolumn{4}{|l|}{ Mother's ethnic status: } \\
\hline Black Caribbean & $3.6(2.2$ to 7.3$)$ & \multirow[t]{4}{*}{$23.0(3)$} & \multirow[t]{4}{*}{$<0.0001$} \\
\hline Black African & $-0.1(-0.2$ to 0.9$)$ & & \\
\hline Not known & $0.06(-0.1$ to 0.2$)$ & & \\
\hline Not black (reference) & 0 & & \\
\hline
\end{tabular}

${ }^{*}$ Parents born non-endemic region, mother not black.

Anti-HTLV was rare in infants with mothers under 26 years old (table 4 ), and prevalence increased greatly with maternal age among all groups at risk of HTLV infection $\left(\chi^{2}=12.6, \mathrm{df}=1, \mathrm{P}=0.0004\right)$. Prevalence was higher in women born in the Caribbean than black Caribbean women born in non-endemic areas (relative risk $2.9,95 \%$ confidence interval 1.2 to 7.1 ). This effect was not significant after age was controlled for, but the data remained consistent with a substantial excess risk (relative risk 1.9, 0.8 to 4.9 ).

Seroprevalence increased from non-metropolitan districts, through outer London, to inner London (table 5). However, this geographical variation can be attributed to distribution of the risk groups. Using only samples for which the presence or absence of risk group was known, we found that the significant trend $\left(\chi^{2}=11.6, \mathrm{df}=1, \mathrm{P}=0.0007\right)$ was eliminated after risk

Table 4 Seroprevalence of HTLV per 1000, by mother's age for babies whose mother's country of birth was also known. Samples with indeterminate results (shown in parentheses) are included in seroprevalence estimates

\begin{tabular}{|c|c|c|c|c|c|c|c|c|c|}
\hline \multirow[b]{2}{*}{ Maternal age } & \multicolumn{3}{|c|}{ Mother born in Caribbean } & \multicolumn{3}{|c|}{ Mother born in other endemic region } & \multicolumn{3}{|c|}{$\begin{array}{l}\text { Black Caribbean mother born in } \\
\text { non-endemic region }\end{array}$} \\
\hline & Positive & Total & Prevalence & Positive & Total & Prevalence & Positive & Total & Prevalence \\
\hline$<21$ & 0 & 42 & 0 & 0 & 108 & 0 & 0 & 142 & 0 \\
\hline $21-25$ & 0 & 85 & 0 & 1 & 341 & 2.9 & 0 & 226 & 0 \\
\hline $26-30$ & 2 & 133 & 15.0 & $1(1)$ & 904 & 2.2 & 2 & 408 & 4.9 \\
\hline $31-35$ & $1(1)$ & 129 & 15.5 & 5 & 898 & 5.6 & 6 & 412 & 14.6 \\
\hline$>35$ & 8 & 233 & 34.3 & 3 & 409 & 7.3 & 1 & 139 & 7.2 \\
\hline Total & $11(1)$ & 622 & 19.3 & $10(1)$ & 2660 & 4.1 & 9 & 1327 & 6.8 \\
\hline
\end{tabular}

Table 5 HTLV seroprevalence per 1000 births by risk group and type of district of birth for samples with known district of birth. Seroprevalence is an average of minimum and maximum estimates

\begin{tabular}{|c|c|c|c|c|c|c|c|c|c|}
\hline \multirow[b]{2}{*}{ Mother's place of birth and ethnic status } & \multicolumn{3}{|c|}{ Inner London } & \multicolumn{3}{|c|}{ Outer London } & \multicolumn{3}{|c|}{ Non-metropolitan districts } \\
\hline & Positive* & Total & Prevalence & Positive* & Total & Prevalence & Positive* & Total & Prevalence \\
\hline Born in Caribbean & $7(1)$ & 460 & 16.3 & 7 & 374 & 18.7 & 1 & 80 & 12.5 \\
\hline Born in other endemic region & $9(1)$ & 2362 & 4.0 & 1 & 1096 & 0.9 & 1 & 149 & 6.7 \\
\hline Black Caribbean, born in non-endemic region & 5 & 855 & 5.8 & 4 & 418 & 9.6 & 0 & 55 & 0 \\
\hline Not black Caribbean, born in non-endemic region & $2(1)$ & 14752 & 0.17 & 1 & 11982 & 0.08 & $1(1)$ & 10489 & 0.14 \\
\hline $\begin{array}{l}\text { Region of birth unknown or non-endemic, ethnic status } \\
\text { not known }\end{array}$ & 6 & 11149 & 0.54 & $15(1)$ & 32334 & 0.48 & 6 (1) & 39104 & 0.17 \\
\hline Total & $29(3)$ & 29578 & 1.03 & $28(1)$ & 46204 & 0.62 & $9(2)$ & 49877 & 0.20 \\
\hline
\end{tabular}


Table 6 Estimates of number of pregnancies in United Kingdom each year in which mother is infected with HTLV. Central estimates are an average and confidence limits the most extreme of those obtained including and excluding indeterminate results as seropositive

\begin{tabular}{|c|c|c|c|}
\hline Risk category & $\begin{array}{c}\text { Prevalence per } \\
1000 \text { births } \\
(95 \% \mathrm{Cl})\end{array}$ & $\begin{array}{l}\text { No of } \\
\text { births }\end{array}$ & $\begin{array}{l}\text { Expected No of } \\
\text { infected women } \\
(95 \% \mathrm{CI})\end{array}$ \\
\hline Born in Caribbean & $16.9(9.2 \text { to } 28.3)^{*}$ & $2750 \S$ & 46.6 (25 to 78$)$ \\
\hline Born in other endemic region & $3.2(1.5 \text { to } 5.9)^{*}$ & 82009 & 26.1 (12 to 48$)$ \\
\hline Black Caribbean, born in non-endemic regions & $6.8(3.1$ to 12.9$) \dagger$ & $8000^{* *}$ & $54.3(25$ to 103$)$ \\
\hline \multicolumn{4}{|l|}{ Not black Caribbean, born in non-endemic regions: } \\
\hline Inner London, principal cities & $0.35(0.14$ to 0.70$) \ddagger$ & $72000 \dagger \dagger$ & $25.0(10$ to 50$)$ \\
\hline Rest of United Kingdom & $0.11(0.01$ to 0.32$) \dagger$ & 626050 & 69.7 (7 to 201) \\
\hline Total & & 720000 & 223 (113 to 347 ) \\
\hline
\end{tabular}

*Data from table 2

†Data from table 5 .

†Pooled estimate $9 / 24498$ based on our figures for inner London 3/14 752 (table 5) combined with 6/9746 previously reported in similar districts. ${ }^{13} 141920$

$\S$ Birth registration statistics. ${ }^{26}$

IBased on unpublished birth registration data supplied by Office for National Statistics.

${ }^{* *}$ Assumes that $1.217 \%$ births are to black Caribbean women, based on proportion of 0-4 year olds in Great Britain recorded as black Caribbean and $20 \%$ of those recorded as black other, ${ }^{27}{ }^{28}$ and assuming that $87 \%$ of black Caribbeans of child bearing age are born in Britain. ${ }^{29}$

t+Office for National Statistics. ${ }^{30}$

group was controlled for $\left(\chi^{2}=0.4, \mathrm{df}=1, \mathrm{P}=0.5\right)$. In inner London, an estimated $90 \%(22 / 24.5)$ of seropositive samples occurred in babies with a maternal risk factor compared with $92 \%(11 / 12)$ in outer London and $57 \%(2 / 3.5)$ in non-metropolitan areas.

\section{Overall prevalence among pregnant women in United Kingdom}

To project our seroprevalence findings across the whole of the United Kingdom we multiplied risk group specific prevalence estimates from this study and elsewhere into population estimates (table 6). We assumed that seroprevalence is homogeneous within groups across the country. This assumption is supported by the preceding analysis for North Thames (table 5), although we stratified the low risk into two groups. The overall number of pregnant women in the United Kingdom infected each year with HTLV is predicted to be 223 (95\% confidence interval 113 to 347) out of a total 720000 , representing an overall prevalence of 0.31 per 1000 (0.16 to 0.48$)$. The main source of uncertainty is the small numerator in the majority (lowest risk) group, which may account for between $6 \%$ and $58 \%$ of maternal infection.

\section{Discussion}

Our results agree well with what is known about the endemicity of HTLV in the Caribbean, west and central Africa, and elsewhere. ${ }^{13}$ The rapid increase in seroprevalence with age and the low seroprevalence in the youngest groups (table 4) point to sexual contact as the primary mode of transmission among women of child bearing age, with only a small fraction attributable to breast feeding. This is also consistent with reports from Africa, Jamaica, and South America. $^{31-33}$ The finding of 1.1 per 1000 seroprevalence in inner London is comparable with estimates of 1.4 to 3.9 per 1000 from smaller studies set in similar areas. $^{13} 1416$ 19-21

The precise prevalence of HTLV-II remains in doubt. Anti-HTLV-II was detected in two of the 126010 samples $(0.016$ per 1000$)$. However, untyped anti-HTLV positive results are more frequent in samples from Africa than from the Caribbean (table 1), and one or more of the three untyped African samples may be HTLV-II. The gelatin particle agglutination assay is equally sensitive to anti-HTLV-I and antiHTLV-II. ${ }^{34}$ However, the serum antibody titre of patients with HTLV-II may be lower than that of patients with HTLV-I, ${ }^{35}$ and therefore more eluates may have fallen below the detection limit. On the other hand, the 59:2 ratio of HTLV-I to HTLV-II recorded here is similar to the 32:1 reported in a recent study based on serum samples in London. ${ }^{21}$

\section{Screening implications}

Several investigators have urged that antenatal screening for HTLV be considered in the United Kingdom in order to prevent vertical transmission of HTLV through breast feeding. The 233 a year nationwide antenatal prevalence of HTLV predicted in this study is comparable to the recent 330 a year estimate for HIV. ${ }^{36}$ Furthermore, the estimated prevalence of HTLV of 0.06-0.12 per 1000 births among those with no known risk factors in North Thames compares with the prevalence of HIV of 0.10 per 1000 births among United Kingdom born women with United Kingdom born partners reported in the same region. ${ }^{22}$

The United Kingdom has recently joined many other countries in recommending universal antenatal testing for $\mathrm{HIV},{ }^{37}$ but the arguments for antenatal HTLV testing may be less compelling. Although HTLV may be transmitted to $20 \%$ of children breast fed for a prolonged period, the transmission rate is only $5 \%$ with three months' breast feeding. ${ }^{9-11}$ In Britain 34\% of mothers do not breast feed at all, and only $35 \%$ breast feed for over 3 months. ${ }^{38}$ Breast feeding may be more prolonged among women born in endemic areas, but these women account for only $32 \%$ of prevalent cases (table 6). The rate of vertical transmission of HTLV in the United Kingdom is therefore likely to be under $10 \%(22 / 223)$, which could be reduced to $2.7 \%(6 / 223)$ by formula feeding. ${ }^{9}$ Not only is the burden of preventable infection therefore quite low, but the lifetime risks of HTLV related disease are also small: $1-5 \%$ for adult T cell leukaemia/lymphoma, ${ }^{7}$ and $0.25-3 \%$ for HTLV-1 associated myelopathy and tropical spastic paraparesis. ${ }^{139}$ Maternal infection may therefore lead to disease in only $0.1 \%$ to $1 \%$ of offspring.

The potentially negative impact of a maternal diagnosis of HTLV on the family's quality of life is a further critical factor, as between 10 and 20 infected women would need to be diagnosed to prevent one paediatric infection, and no effective treatments exist for HTLV infection or HTLV related diseases. A thorough economic evaluation would establish whether there is a net benefit to diagnosing an HTLV infected pregnant woman. If there is a benefit, our findings suggest that targeting high risk women or universal testing in high prevalence areas could identify most women infected with HTLV at relatively low cost.

The conjecture that HTLV may be as frequent in the general United Kingdom population as HIV also has implications for blood donor screening. The prevalence of HTLV infection in women with no risk factors and low risk partners of 0.06-0.12 per 1000 births compares with the $0.05 / 1000(5 / 96720)$ prevalence reported in blood donors in north London in $1993^{40}$ and $0.014 / 1000(1 / 76452)$ in the north of 
England. ${ }^{41}$ The prevalence of HIV nationally in 1998 was $0.04 / 1000$ in eligible first time blood donations and $0.004 / 1000$ in repeat donations. ${ }^{42}$ Although the risks of infection and disease after contaminated transfusion are less with HTLV than with HIV, ${ }^{43}{ }^{44}$ screening first time donors for HTLV would not be inconsistent with the present policy of screening all donations for HIV.

Contributors: AEA conceptualised the study and analyses, drafted the paper, and is the guarantor. ME carried out the laboratory work supervised by SP. JW carried out all data processing including data linkage and anonymisation. The study is part of the HTLV European Research Network International Antenatal Seroprevalence Study (HERNIAS) Concerted Action, which is coordinated by GPT and JNW. All authors contributed to the paper.

Funding: European Community Biomed Programme, Contract BMH4 CT97- 2710.

Competing interests: None declared.

1 Kaplan JE, Khabbaz RF. The epidemiology of human T-lymphotropic virus types I and II. Rev Med Virol 1993;3:137-48.

2 Hall WW, Ishak R, Zhu SW, Novoa P, Eiraku N, Hidehiro T, et al. Human T lymphotropic virus II (HTLV-II): epidemiology, molecular properties and clinical features of infection. J AIDS 1996;13(suppl 1):S204-14.

3 Taylor GP. The epidemiology of HTLV-I in Europe. J AIDS 1996;13(suppl 1):S8-14

4 Taylor GP, McClure MO. Human oncoretroviruses. In: Arrand JR, Harper DR, eds. Viruses and human cancer. Oxford: Bios Scientific, 1998:109-42.

5 Gessain A, Rahieux R, de Thé G. Genetic variability and molecular epidemiology of human and simian T cell leukemia/lymphoma virus type I.J AIDS 1996;13(suppl 1):S132-45.

6 Yamashita M, Ido E, Miura T, Hayami M. Molecular epidemiology of HTLV-I in the world. J AIDS 1996;13(suppl 1):S124-31

7 International Agency for Research on Cancer. Monographs on the evalua tion of carcinogenic risk to humans. Vol 67. Human immunodeficiency viruse and human T-cell lymphatropic viruses. Lyons: IARC, 1996.

8 Lee H, Swanson P, Shorty VS, Zack, JA, Rosenblatt JD, Chen ISY. High rate of HTLV-II infection in seropositive IV drug users from New Orleans. Science 1989:244:472-5.

9 Hino S, Katamine S, Miyata H, Tsuji Y, Yamabe T, Miyamoto T. Primary prevention of HTLV-I in Japan. J AIDS 1996;13(suppl 1):S199-203.

10 Takezaki T, Tajima K, Ito M, Ito S-I, Kinoshita K-I, Tachibana K, et al. Short-term breast-feeding may reduce the risk of vertical transmission of HTLV-I. Leukemia 1997;11(suppl 3):60-2

11 Katamine S, Kinoshita K, Doi H, Ishimaru T, Kurokawa K, Tsuji Y, et al. Intervention for 10 years on milk-borne transmission of HTLV-I in an endemic area, Nagasaki, Japan [abstract]. Ninth international conference on human retrovirology, April 5-9 1999, Kagoshima, Japan. J AIDS 1999;20:A23.

12 Wiktor SZ, Pate EJ, Rosenberg PS, Barnett M, Palmer B, Medeiros D, et al Mother-to-child transmission of human T-cell lymphotropic virus type associated with prolonged breast-feeding. J Hum Virol 1997;1:38-45.

13 Nightingale S, Orton D, Ratcliffe D, Skidmore S, Tosseill J, Desselberger U. Antenatal survey for the seroprevalence of HTLV-I infections in the West Midlands, England. Epidemiol Infect 1993;110:379-87.

14 Hale A, Leung T, Sivasubramanian S. Prevalence of antibodies to HTLV in antenatal clinic attenders in south east London. I Med Virol 1997:52:326-9.

15 HTLV European Research Network. Seroepidemiology of the human T-cell leukaemia/lymphoma viruses in Europe. J AIDS 1996;13:68-77.

16 Otigbah C, Kelly A, Aitken C, Norman J, Jeffries D, Erskine DJ. Is HTLV-I status another antenatal screening test that we need? BrJ Obstet Gynaecol 1997;104:258-60.

17 Weber JN, Taylor GP. Antenatal screening is important. BMJ 1996;312:702.

18 Hanchard B. Adult T-cell leukemia/lymphoma in Jamaica: 1986-1995. J AIDS 1996;13(suppl 1):S20-5.

19 Tosswill JHC, Ades AE, Peckham CS, Mortimer P, Weber J. Infection with human T cell leukaemia/lymphoma virus type I in patents attending an antenatal clinic in London. BMJ 1990;301:95-6.

20 Banatvala JE, Chrystie IL, Palmer SJ, Kenney A. Retrospective study of HIV, hepatitis B, and HTLV-I infection at a London antenatal clinic. Lancet 1990;335:860-1.

21 Donati M, Seyedzadeh H, Leung T, Blott M, Zuckerman M. Prevalence of antibody to human $\mathrm{T}$ cell leukaemia/lymphoma virus in women attending antenatal clinic in south east London: retrospective study. $B M J$ 2000;320:92-3

22 Ades AE, Walker J, Botting B, Parker SP, Cubitt C, Jones R. Effect of the world-wide epidemic on HIV prevalence in the UK: record linkage in anonymous neonatal seroprevalence surveys. AIDS 1999;13:2437-43.

23 Parker SP, Cubitt WD, Ades AE. A method for the detection and confirmation of antibodies to hepatitis C virus in dried blood spots.J Virol Meth 1997;68:199-205.

24 Parker SP, Taylor SB, Ades AE, Cubitt D, Peckham CS. Use of dried blood spots for the detection and confirmation of HTLV-I specific antibodies for epidemiological purposes. J Clin Path 1995;45:904-7.

25 Wacholder S. Binomial regression in GLIM: estimating risk ratios and risk differences. Am J Epidemiol 1986;123:174-84.

\section{What is already known on this topic}

Human T cell leukaemia/lymphoma virus (HTLV) type 1 is associated with adult $\mathrm{T}$ cell leukaemia and progressive neurological disease; HTLV-II is less common in the United Kingdom but is also associated with serious disease

The viruses can be transmitted sexually, percutaneously, and from mother to child

Antenatal screening is carried out in Japan and many countries screen blood donations for HTLV

\section{What this study adds}

The prevalence of HTLV among pregnant women in the United Kingdom is estimated to be 0.31 per 1000 , similar to the prevalence of HIV

In inner city areas about $90 \%$ of HTLV is associated with birth or ethnic origin in endemic areas, compared to $50 \%$ in non-metropolitan areas.

Antenatal HTLV testing is likely to be less beneficial economically and clinically than antenatal HIV testing but should be fully evaluated

Screening of blood donations should be considered

26 Office for National Statistics. Birth statistics. London: Stationery Office, 1998. (Series FM1 No 25.)

27 Office of Population Censuses and Surveys. 1991 Census ethnic group and country of birth: Great Britain. Vol 2. London: HMSO, 1993.

28 Owen D. Black-other: the melting pot. In: Peach C, ed. Ethnicity in the 199 census, volume 2. The ethnic minority populations of Great Britain. London: HMSO, 1996.

29 Matheson J, Pullinger J, eds. Social trends 29. London: Stationery Office, 1999.

30 Office for National Statistics. Key population and vital statistics. London: Stationery Office, 1998. (Series VS No 22, PP1 No 18.)

31 Bhigjee AI, Vinsen C, Windsor IM, Gouws E, Bill PLA, Tait D. Prevalence and transmission of HTLV-I infection in Natal/KwaZulu. S Afr Med J 1993;83:665-7.

32 Murphy EL, Figueroa JP, Gibbs WN, Holding-Cobham M, Cranston B, Malley K, et al. Human T-lymphotropic virus type I (HTLV-I) seroprevalence in Jamaica. Am J Epidemiol 1991;133:1114-24.

33 Plancoulaine S, Buiges RP, Murphy EL, Van Beveren M, Pouliquen J-F, Joubert M, et al. Demographic and familial characteristics of HTLV-I infection among an isolated, highly endemic population of African origin in French Guiana. Int J Cancer 1998,76,331-6.

34 Andersson S, Thorstensson R, Godoy Ramirez KG, Krook A, Von Sydowe M, Dias F, et al. Comparative evaluation of 14 immunoassays for detection of antibodies to the human T-lymphotropic virus types I and II using panels of sera from Sweden and West Africa. Transfusion 1999;39:845-51.

35 Kaplan JE, Khabbaz RF, Murphy EL, Hermansen S, Roberts C, Lal R, et al. Male-to-female transmission of human T-cell lymphotropic virus types I and II: association with viral load.J AIDS Hum Retrovir 1996;12:193-201

36 Department of Health. Prevalence of HIV in England and Wales in 1998 Annual report of the unlinked anonymous monitoring programme. London: DoH, 1999.

37 Ades AE, Sculpher MJ, Gibb DM, Ratcliffe J, Gupta R. A cost-effectivenes analysis of antenatal HIV screening in the UK. BMJ 1999;319:1230-4.

38 Foster K, Lader D, Cheesbrough S. Infant feeding 1995. London: Stationery Office, 1997.

39 Tosswill JHC, Taylor GP, Tedder RS, Mortimer PP. HTLV-I/II associated disease in England and Wales 1993-7: retrospective review of serology requests. BMJ 2000;320:611-2.

40 Brennan M, Runganga J, Barbara JAJ, Contreras M, Tedder RS, Garson JA, et al. Prevalence of antibodies to human T cell leukemia/lymphoma virus in blood donors in North London. BMJ 1993;307:1235-9.

41 Flanagan P, McAlpine L, Ramskill SJ, Smith AG, Eglin R, Parry JV, et al Evaluation of a combined HIV-1/2 and HTLV-I/II assay for screening blood donors. Vox Sang 1995;68:220-4

42 Surveillance of viral infections in donated blood: England and Wales, 1998. Comm Dis Rep 1999;9:340

43 Donegan E, Lee H, Operkalski EH, Shaw GM, Kleinman SH, Busch MP, et al. Transfusion transmission of retroviruses: human T-cell lymphotropic virus types I and II compared with human immuno-deficiency virus type I. Transfusion 1994;34:478-83.

44 Tynell E, Andersson S, Lithander E, Arneborn M, Blomberg J, Hanson $\mathrm{HB}$, et al. Screening for human T cell leukaemia/lymphoma virus among blood donors in Sweden: cost effectiveness analysis. BMJ 1998;316: 1417-22.

(Accepted 23 February 2000) 